\title{
On the Mode of Transmission of Hereditary Diabetes
}

\author{
I. Pavei and R. Pieptea
}

Received: February 29, 1968

Summary. Using the case records of 14000 diabetics followed up in the Antidiabetic Centre of Bucharest for $1-26$ years, the authors have studied the problem of the mode of transmission of hereditary diabetes. The analysis, which takes into consideration four different aspects representing four stages of investigation, indicates a dominant transmission for diabetes. - 1. Consanguinity. In a group of 49 consanguine marriages, diabetes was found in 14 of 100 direct descendants. The probability of diabetes would have attained $24.6 \%$ if all had lived up to 80 years. This fact, to which we must add the late onset of diabetes in the offspring and the absence of a massive appearance of diabetes in siblings, raises doubts regarding the hypothesis of the recessive transmission of hereditary diabetes. - 2. Diabetic Couples. In 385 families in which both parents were diabetic there were 1,173 descendants; 326 of these suffered from diabetes $(27.7 \%)$. The probability of diabetes calculated for a lifespan of 90 years for all the progeny would have been in the authors' material of $37.7 \%$. This figure shows that the parents, who were diabeties of the hereditary type, could only have had heterozygotic genetic structures, pleading for the dominant transmission of hereditary diabetes mellitus. - 3. Dia betes in Multiple Successive Generations. In 113 of the 3,430 pedigrees studied, the disease could be noticed in 3 successive generations, which after the necessary corrections gives a proportion of $8.15 \%$; in 4 pedigrees diabetes was found in 4 successive generations $(1.19 \%)$. - 4. Anteposition presents a net statistical significance and upholds in the authors' opinion the dominant transmission of diabetes. - These findings ( 3 and 4 ) imply the dominant transmission of hereditary diabetes.

\section{Le mode de transmission du diabète héréditaire}

Résumé. Les auteurs ont étudié le problème du mode de transmission du diabète héréditaire sur 14000 diabétiques suivis au Centre Antidiabétique de Bucarest pendant $1-26$ ans. L'analyse qui prend en considération 4 aspects différents représentant 4 stades de l'investigation, a conclu à la transmission dominante du diabète. - 1. Consanguinité. Dans un groupe de 49 mariages consanguins, le diabète a été trouvé chez 14 des 100 descendants directs. La probabilité du diabète aurait atteint $24.6 \%$, si tous avaient vécu jusqu'à l'âge de 80 ans. Ce fait, auquel nous devons ajouter l'apparition tardive du diabète dans la descendance et l'absence d'apparition rnassive du diabète chez les frères et soeurs, soulève des doutes sur l'hypothèse de la transmission récessive du diabète héréditaire. - 2. Couples de diabétiques. Dans 385 familles chez lesquelles les deux parents étaient diabétiques, il y a 1173 descendants; 326 souffraient de diabète $(27,7 \%)$. La probabilité du diabète calculée pour une durée de vie de 90 années pour toute la progéniture aurait été de $37.7 \%$ dans le matériel des auteurs. Ce chiffre indique que les parents, diabétiques de type héréditaire ne pouvaient avoir que des structures génétiques hétérozygotes, ce qui plaide en faveur de la transmission dominante du diabète sucré héréditaire. 3. Diabète dans plusieurs générations successives. Pour 113 des 3430 arbres généalogiques étudiés, la maladie a pu être trouvée pendant 3 générations successives, ce qui donne, après les corrections nécessaires, une proportion de $8.15 \%$; dans 4 arbres généalogiques le diabète a été trouvé dans 4 générations successives $(1.19 \%)$. - 4. L'antéposition a une nette signification statistique et confirme, dans l'opinion des auteurs, la transmission dominante du diabète. Ces résultats ( 3 et 4) peuvent être pris comme preuve de la transmission dominante du diabète héréditaire. - Le caractère irrégulier de la maladie a attiró l'attention des auteurs sur le rôle protecteur de l'allèle non-porteuse des hétérozygotes et sur l'importance des facteurs environnants dans l'instauration de la maladie.

\section{Erbgang des genetisch bedingten Diabetes}

Zusammenfassung. Die Autoren untersuchten das Problem des Firbgangs des Diabetes an 14000 Personen, die in der Zentralstelle für Diabetes-Behandlung in Bukarest während 1-26 Jahren beobachtet wurden. Die Analyse berücksichtigt 4 verschiedene Aspekte, die 4 verschiedene Stadien der Untersuchungsreihe darstellen, und kommt zur Annahme einer dominanten Vererbung des Diabetes. - 1. Konsanguinität. In einer Gruppe von 49 Verwandtenehen wurde Diabetes nur bei 14 von 100 direkten Nachkommen gefunden. Die Wahrscheinlichkeit hätte $24.6 \%$ erreicht, wenn alle ein Alter von 80 Jahren erlebt hätten. Diese Tatsache, zu der wir den späten Beginn des Diabetes bei den Nachkommen und das Fehlen massiver DiabetesErscheinungen bei den Geschwistern zählen müssen, läßt die Annahme eines rezessiven Erbgangs für den ererbten Diabetes als fraglich erscheinen. - 2. Diabetische Ehepaare. In 385 Familien, in denen beide Eltern Diabetiker waren, fanden sich 1173 Nachlommen, von denen 326 $(27.7 \%)$ an Diabetes litten. Die Wahrscheinlichkeit eines Diabetes bei der gesamten Nachkommenschaft unter der Annahme einer Lebenserwartung von 90 Jahren hätte im Material der Autoren bei $37.7 \%$ gelegen. Diese Zahl zeigt, daß diese Eltern mit erblichem Diabetes eine heterozygote genetische Strulktur aufwiesen und sprechen für einen dominanten Frbgang des ererbten Diabetes, - 3. Diabetes in mehreren aufeinanderfolgenden Generationen. In 113 von 3430 untersuchten Stammbäumen konnte die Krankheit über 3 aufeinanderfolgende Generationen beobachtet werden, was nach den notwendigen Korrekturen einen Prozentsatz von 8.15 ergibt; in 4 Stammbäumen fand sich ein Diabetes in 4 aufeinanderfolgenden Generationen (1.19\%). - 4. Die Anteposition läßt sich statistisch eindeutig nachweisen und spricht nach Ansicht der Autoren für eine dominante Vererbungsweise des Diabetes. Auch die unter 3. und 4, aufgeführten Befunde sprechen für einen dominanten Erbgang des erblichen Diabetes. Das unregelmäBige Auftreten der Erkrankung lenkte die Aufmerksamkeit der Verfasser auf die schützende Rolle eines Nicht-Träger-Allels der Heterozygoten und auf die Bedeutung von Umgebungseinflüssen bei der Auslösung der Erkrankung.

Key-words: Dominant transmission, consanguinity, diabetic, couples, anteposition, diabetes, heredity. 
Since 1933, when Pincus and Wirte [16] demonstrated the hereditary character of diabetes mellitus, the most disputed question has been that of the mode of transmission of the disease. Theoretically this would permit a better understanding of the genetios of diabetes; practically, if a solution to this problem is not found there can be no correct prophylaxis of hereditary diabetes from either the social or the individual points of view.

Clinical studies on diabetic heredity were insufficient because of the small size of the human family and the large size of one generation. The small number of pedigrees that extend over several generations is insufficient material to permit extrapolation and generalization. These conditions led to extremely varied, and often downright opposite results. All the authors found exceptions to the main pattern they proposed; so that to-day, it may be justly stated that the mode of transmission of hereditary diabetes is still an open question.

\section{The hypotheses admitted}

Dominant transmission. This assumption sustained by Levit and Pestkova [10], ILse von KrIws [7], GÜNTHER [5], etc., was based, among other findings, upon the similarity found between the prevalence of diabetes among the probands' parents and the siblings. In 1934, LAWRENom [9] considered the hypothesis of the double dominant gene as more adequate. Of late GRönBERg, LaRsson and Jung [3 bis] have admitted that D.M. may be conditioned by a major sexlinked dominant gene.

Recessive transmission has been accepted by most authors in the last few decades. Evocative in this connection is the disappearance of the disease in the course of one or several generations. Workers such as Pincus and White [17], Allen [1], Thompson and WATSON [21], Steinberg and WILDER [20], as well as other research workers, have lent support to this assumption.

Intermediate modalities had also to be admitted, since the principles of Mendel's laws could not be fully met by the two hypotheses. Thus, CAMMIDGE [2] considered that in the adult the transmission of diabetes is dominant, whereas the transmission of infantile or juvenile diabetes is recessive. HARRIS [6] believed that between these two forms there is only a difference of genetic "dose". GRÜNNET [4] admitted the existence of multiple mutant genes which appear to act separately or together. LAMY, FrízaI and $R_{E Y}$ [8] assumed that next to the principal mutant gene, there are also other "minor" carrier genes that condition the "functional capacity" of the pancreas. SIMPSOn [19] and NeEL et al. [11] formulated the hypothesis of multifactorial transmission. According to NIrSson [11 bis] "an autosomal recessive mode of inheritance seemed to be the most likely transmission of D.M. Dominant inheritance seemed to be less likely, but could not be excluded."
Although the hypotheses of intermediate transmission are more comprehensive and more readily adaptable to the various casuistics, they are now admitted to a lesser extent; Post [19] demonstrated statistically that diabetes is controlled by a single gene, in a single locus.

\section{Material and Method}

In the following pages the mode of transmission of hereditary diabetes will be approached, through an analysis of the 14000 diabetics filed in the Antidiabetic Centre of Bucharest, up to 1 May 1967, taking into consideration:

- The diabetic descendants of consanguine marriages in families with diabetes mellitus;

- The appearance of diabetes among the offspring of families in which both parents were diabetics;

- The presence of diabetes in multiple succesive generations;

- The anticipation phenomenon.

The last two categories have already been studied by us [14]; and reference will be made to these two eategories only in so far as the data lend support to our conclusions concerning the mode of transmission of diabetes.

For study of the descendants of consanguine marriages, or of diabetic couples, simple evaluation of the proportions is not sufficient. As a rule, diabetes appears late, after 30 and especially after 40 years. Because of the number of the descendants lost to evidence, for one reason or another, many cases of diabetes may fail to be detected, and the fact that the offspring is not followed up until the age of 80 or 90 years, when the onset of diabetes is still frequent, may evidently falsify the statistics of diabetes; the determination of carbohydrate metabolism cannot anticipate the future of the offspring for many years. On the other hand, the methods available to-day cannot be applied in mass investigations.

This obliges us to draw conclusions about the prevalence of hereditary diabetes by calculating the probability of the disease starting from the total number of the descendants $(N)$, the number of diabetic descendants $(n)$, the age at which diabetes developed in the diabetic descendants (the average weight per decade of age $=K$ ), and the age to which the nondiabetic descendants were followed up. Thus, $n_{i}$ stands for the number of patients that developed the disease in decade $i ; n_{j}$ for the number descendants without diabetes up to decade $i$.

Under these conditions, the probability of the onset of diabetes, $p$, may be calculated according to formula ${ }^{1}$

$$
p=\frac{n}{N-\sum_{j=1}^{k-1} n_{j}^{\prime} \cdot p_{j}}
$$

1 Probability was calculated together with M. Dragomirescu of the Institute of Mathematical Research of the R.S.R. Academy. 
The probability $p_{j}$ of an individual developing diabetes after decade $i$, provided he does develop it, may be calculated according to formula:

$$
p_{j}=\frac{n_{i+1}+n_{i+2}+N_{i+3}+\cdots+n_{\mathrm{k}}}{n}
$$

The figures thus obtained will be compared with the theoretical figures for recessive and for dominant transmission, in an attempt to assess the true value of our data.

Table 1. Consanguinity. The figures show the age at which the patients developed diabetes or to which the nondiabetics were followed up

\begin{tabular}{|c|c|c|c|c|c|c|c|c|c|c|c|c|}
\hline \multirow{3}{*}{$\begin{array}{l}\text { Crt. } \\
\text { no. }\end{array}$} & \multirow{3}{*}{$\begin{array}{l}\text { No. of } \\
\text { pedi- } \\
\text { gree } \\
\text { Anti- } \\
\text { diab. } \\
\text { Centre }\end{array}$} & \multicolumn{4}{|c|}{ Consanguine parents } & \multicolumn{4}{|c|}{ Direct descendants } & \multirow{2}{*}{\multicolumn{2}{|c|}{$\begin{array}{l}\text { No. of } \\
\text { gene- } \\
\text { rations } \\
\text { up to the } \\
\text { common } \\
\text { sibling }\end{array}$}} & \multirow[t]{2}{*}{$\overline{\mathrm{Obs}}$} \\
\hline & & \multicolumn{2}{|c|}{ Diabetics } & \multicolumn{2}{|c|}{$\begin{array}{l}\text { Non-dia- } \\
\text { betias }\end{array}$} & \multicolumn{2}{|c|}{ Diabeties } & \multicolumn{2}{|c|}{ Non-diabetics } & & & \\
\hline & & $\overline{\mathrm{M}}$ & $\overline{\mathbf{F}}$ & $\overline{\mathrm{M}}$ & $\bar{F}$ & $\bar{M}$ & $\mathrm{~F}$ & $\bar{M}$ & $F$ & $\bar{M}$ & $\bar{F}$ & \\
\hline 1. & 586 & & & 60 & 40 & 33,44 & & & & 1 & 2 & a \\
\hline 2. & 588 & 70 & 52 & & & & 43 & & 51 & 1 & 1 & $\mathrm{c}$ \\
\hline 3. & 610 & 71 & 55 & & & & 50,57 & 39,45 & 42,51 & 2 & 2 & $\mathrm{c}$ \\
\hline 4. & 893 & & & 50 & 56 & & & & 33 & 1 & 2 & a \\
\hline 5. & 943 & & & 64 & 60 & & & & 40 & 1 & 1 & $a$ \\
\hline 6. & 1072 & & 52 & 50 & & & & & 51,51 & 2 & 1 & b \\
\hline 7. &, & & 42 & 40 & & & & & & 1 & 1 & $\mathbf{b}$ \\
\hline 8. & 2022 & 76 & 50 & & & 51 & & 38 & 42 & 2 & 2 & $e$ \\
\hline 9. & 2063 & 59 & 51 & & & & & 33,39 & 36,41 & 2 & 2 & c \\
\hline 10. & 2071 & & 45 & 40 & & 31 & & & & 1 & 1 & $b$ \\
\hline 11. & 2187 & 60 & & & 60 & & 52 & 46 & & 1 & 1 & b \\
\hline 12. & 2472 & 34 & 58 & & & 32 & & $27,29,30$ & & 0 & 1 & c \\
\hline 13. & 2842 & & 40 & 40 & & & & 30 & 33,37 & 1 & 1 & $\mathbf{b}$ \\
\hline 14. & 2853 & & & 36 & 40 & & & & 10 & 1 & 1 & $a$ \\
\hline 15. & 2954 & & 60 & 71 & & & & 34,36 & & 1 & 1 & $\mathbf{b}$ \\
\hline 16. & 2966 & 73 & & & 55 & & . & & 8 & 0 & 1 & b \\
\hline 17. & 2974 & & 58 & 50 & & & & 34 & & 1 & 1 & $\mathbf{b}$ \\
\hline 18. & & 56 & & & 50 & & & & & 1 & 1 & $\mathbf{b}$ \\
\hline 19. & 3107 & 70 & & & 24 & & & 45 & 49 & 0 & 1 & $\mathbf{b}$ \\
\hline 20. & 3195 & & 46 & 50 & & & & $13,17,22$ & & 1 & 1 & $\mathbf{b}$ \\
\hline 21. & 3323 & & & 50 & 50 & & & 28 & 24 & 0 & 1 & $a$ \\
\hline 22. & 3550 & & & 30 & 37 & & & & & 1 & 1 & $a$ \\
\hline 23. & 3568 & & 60 & 60 & & & 30 & & 30 & 1 & 1 & b \\
\hline 24. & 3652 & 69 & 60 & & & & & 20,40 & 37 & 2 & $\mathbf{3}$ & c \\
\hline 25. & 4043 & & 61 & $\mathbf{3 0}$ & & & & & 47,52 & 1 & 2 & $\mathbf{b}$ \\
\hline 26. & 4240 & 75 & & & 60 & & & & 38 & 1 & 1 & $b$ \\
\hline 27. & 4521 & 48 & & & 40 & & & 31,47 & 41 & 2 & 2 & b \\
\hline 28. & 4757 & 47 & & & 30 & & & 2 & & 2 & $\overline{2}$ & $\mathrm{~b}$ \\
\hline 29. & 4818 & & & 55 & 50 & & & 15 & 17 & 2 & 2 & $\mathbf{a}$ \\
\hline 30. & 4885 & & & 60 & 60 & 56 & & 54 & 52 & 1 & 1 & a \\
\hline 31. & , & 56 & & & $?$ & & & & & 2 & 1 & $\mathrm{~b}$ \\
\hline 32. & & & & 26 & 33 & & & & & 1 & 1 & a \\
\hline 33. & 6540 & 58 & 75 & & & & & 53,55 & & 1 & 2 & $\mathrm{c}$ \\
\hline 34. & 6625 & & 70 & 70 & & & 4.5 & & 46,53 & 1 & 2 & $b$ \\
\hline 35. & 6934 & & & 43 & 43 & & & & 17 & 1 & $\overline{1}$ & $a$ \\
\hline 36. & 7486 & 67 & & & 63 & & & & 38 & 3 & 3 & $\mathrm{~b}$ \\
\hline 37. & 8209 & & & 50 & 58 & & & $33,39,41$ & & 1. & 2 & $\mathrm{a}$ \\
\hline 38. & 8366 & & 53 & 64 & & & & 28 & & 1 & 1 & $\mathrm{~b}$ \\
\hline 39. & 8635 & & & 68 & 32 & & & 48 & 53 & 1 & 1 & a \\
\hline 40. & 8666 & $?$ & & & 66 & & & 39 & 30 & 1 & 2 & $\mathrm{~b}$ \\
\hline 41. & 8744 & & 40 & 40 & & & & & 45 & 1 & 1 & $\mathrm{~b}$ \\
\hline 42. & 8797 & & & 37 & 37 & & & & 14 & 1 & 1 & $\mathbf{a}$ \\
\hline 43. & 8851 & & & 71 & 71 & 60 & & 72 & $36,48,52$ & 1 & 1 & $a$ \\
\hline 44. & 8935 & 70 & 43 & & & & & 38,43 & & 2 & 3 & $\mathrm{c}$ \\
\hline 45. & 9568 & & & 30 & 25 & & & 50 & 40 & 0 & 1 & a \\
\hline 46. & 10692 & & & 50 & 50 & $\mathbf{3 7}, 60$ & & 3 over 50 & 3 over 50 & 1 & 1 & $a$ \\
\hline 47. & 10795 & & 62 & 67 & & & & & & 1 & 1 & b \\
\hline 48. & 11009 & & 50 & 63 & & & & & 39,42 & 1 & 1 & $\mathrm{~b}$ \\
\hline 49. & 11083 & 30 & & & 50 & & & 40 & $45,47,50$ & 1 & 1 & b \\
\hline
\end{tabular}

Probability $p$ represents the individual's risk of falling ill if he lived for 8 to 9 decades, according to the incidence of our cases of diabetes for different decades of age. This figure would be the more illustrative the greater and more homogenous is the group studied.

\section{Consanguinity}

In the Antidiabetic Centre of Bucharest, 49 consanguine marriages with diabetogenic foci have been filed. Particular attention was paid to the first filial 
generation of these consanguine marriages, consisting of 100 descendants of whom 14 had diabetes. Table 1 gives an analysis of these cases.

The degree of relationship between husband and wife is represented schematically in Fig. 1, which also gives the number of cases for each type of relationship.

As may be seen from Fig. 1, most marriages occured between first cousins (26 of 49), more seldom between a member of the family and his first cousin's daughter (9 of 49), and finally even more seldom between uncle and niece ( 5 of 49) and between second cousins ( 6 of 49 ). In 3 cases the relationship was still further removed.

With reference to the diabetes of consanguine couples, three categories may be distinguished (see Table 1, the last column):

a) healthy husband and wife $=16$ couples

b) diabetic husband or wife $=25$ couples

c) diabetic husband and wife $=16$ couples

The offspring of the consanguine couples are given in Table 2 , in terms of three categories.

Table 2

\begin{tabular}{llllr}
\hline Category & \multicolumn{3}{l}{ Descendants } & \\
\cline { 2 - 5 } & Total & Diabetics & $\begin{array}{l}\text { Non- } \\
\text { diabetics }\end{array}$ & $\%$ Diabetes \\
\hline a & $\mathbf{3 4}$ & 6 & 28 & $\mathbf{1 7 . 6 5}$ \\
b & 40 & $\mathbf{3}$ & 37 & 7.50 \\
c & $\mathbf{2 6}$ & $\mathbf{5}$ & $\mathbf{2 1}$ & $\mathbf{1 9 . 2 0}$ \\
\hline
\end{tabular}

Fig. 2 is a schematic representation of the prevalence of diabetes among the offspring of consanguine marriages in terms of the diabetes of the parents.

The number of non-diabetic descendants is predominant in all three categories. It is likewise worthy of note that the average age to which these descendants were followed up was 38.7 years.

There is no massive appearance of diabetes among siblings: eight families had only one diabetic, and three families two diabetics. In no family did three or more diabetes cases appear. On the other hand, it should be recalled that the descendants of 32 of the 49 consanguine couples were all healthy. Their number attained 62 , and their average age at the time of the survey was 36.4 years. non-diabetic children, 11 in all, although the marriages were consanguine and both husband and wife were diabetic, and the descendants were followed up to the age of 40 . The overall probability of diabetes among the

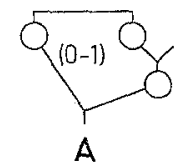

5cases

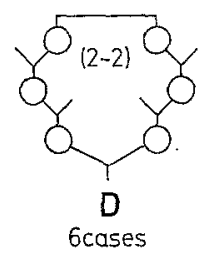

6cases
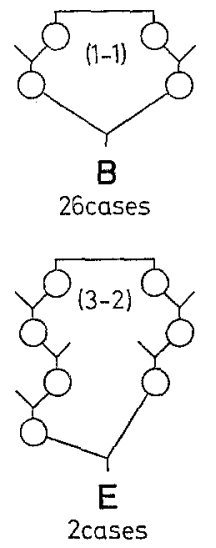

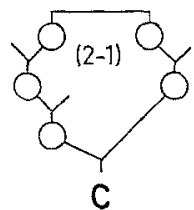

9cases

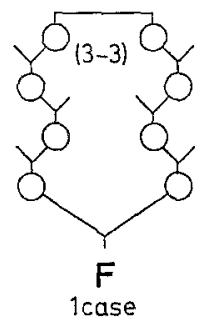

Fig. 1. The degree of relationship of the consanguine couples

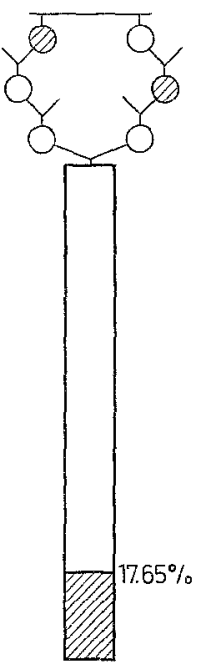

a

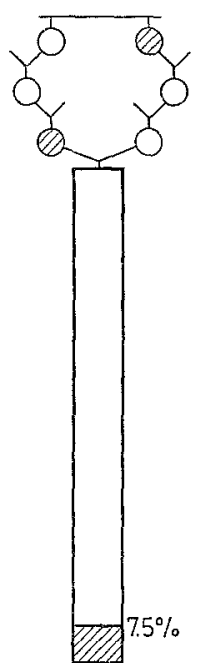

b

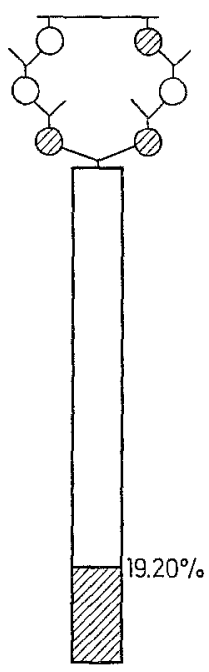

c
Fig. 2. Prevalence of diabetes (mellitus) among the descendants of each of the 3 categories: $a, b$ and $c$

Table 3

\begin{tabular}{llccccccccc}
\hline & Decade I & IT & III & IV & V & VI & VII & VIII & IX & Total \\
\hline$n_{i}$ & 0 & 0 & 1 & 4 & 4 & 5 & 0 & 0 & 0 & 14 \\
$n_{j}$ & 2 & 8 & 10 & 25 & 22 & 6 & 2 & 1 & 0 & 86 \\
$p_{j}$ & 1 & 1 & 0.930 & 0.642 & 0.357 & 0 & 0 & 0 & 0 & - \\
\hline
\end{tabular}

Finally, particular mention should be made of the eight families of group C. Half of them (couples, no. $2,3,8$ and 12) had both diabetic and non-diabetic children ( 5 diabetics among 15 descendants). The other four families (couples, no. 9, 24, 33 and 44) had only offspring of consanguine couples has likewise been calculated according to the above formula, which permits exclusion of the age factor. The data of the problem are presented analytically in Table 3 (for symbols see under Material and Method). 

mula:

The probability of diabetes, $p$, is given by the for-

$$
p=\frac{n}{\mathrm{~N}-\sum_{j=1}^{k-1} n_{j}^{\prime} \cdot p_{j}}
$$

Hence:

$n_{j} \cdot p_{j}=2.1+8.1+10.0 .93+25.0 .642+22.0 .357=$

$$
=43.20
$$

so that:

$$
p=\frac{14}{100-43.20}=\frac{14}{56.8}=0.246
$$

The probability of diabetes among the descendants of consanguine couples is $24.6 \%$. In order to interpret this finding, it must be compared with the overall value to be expected $(P)$ if the transmission of diabetes were recessive. Theoretically this would be:

$$
\begin{aligned}
& P=\text { for the couples of group } a=0.25-0.50 \\
& P=\text { for the couples of group } b=0.50-0.75 \\
& P=\text { for the couples of group } c=1
\end{aligned}
$$

The ideal probability of diabetes $P$ for the entire group of descendants, calculated with the lowest liminal figures, would be:

$$
P=\frac{34 \cdot 0.25+40 \cdot 0.50+26 \cdot 1}{100}=\frac{54.5}{100}=0.545
$$

If diabetes were exclusively transmitted by homozygote structures the probability of diabetes among the descendants would rise to $54.5 \%$. The difference between the actual figure of $24.6 \%$ and the theoretical figure is statistically significant, which shows that the overall probability of diabetes among the descendants of consanguine couples does not lend support to recessive transmission.

The above results from a study of the offspring of consanguine couples give rise to doubts concerning the hypothesis of the recessive transmission of hereditary diabetes.
The probability of diabetes $p$ is given by the formula:

$$
p=\frac{n}{N-\sum_{j=1}^{k-1} n_{j}^{\prime} \cdot p_{j}}
$$

$n^{\prime}{ }_{j} \cdot p_{j}$ will be given by the addition of the following products:

$15 \times 1 ; 24 \times 0.96 ; 85 \times 0.872 ; 164 \times 0.651 ; 223 \times 0.307$ $202 \times 0.089$; and $101 \times 0.0215$, giving a total of 307.534 .

So that:

$$
p=\frac{326}{1173-307.534}=\frac{326}{865.466}=0.3765
$$

It follows therefore that if all the descendants of the diabetic couples lived 90 years, the proportion of diabetios would be of $37.65 \%$.

If the transmission of diabetes was recessive, the partners of the 385 couples would be homozygotes, and the probability of diabetes would then rise to $100 \%$ among the descendants.

The fact that actually $72.30 \%$ of the offspring of diabetic parents did not suffer from diabetes, and that in all likelihood $62.35 \%$ would not develop diabetes even if they lived to be 90 , shows that both parents, the partners of 385 couples, had, from the viewpoint of carbohydrate metabolism, a heterozygote genetic structure. Hence, the dominant transmission of diabetes may be sustained.

\section{Diabetes in multiple successive generations}

A study on this subject has already been published [14] and will be brought into discussion only in as far as the facts confirm the above conclusions. In the material of the Antidiabetic Centre of Bucharest there are 113 pedigrees with diabetes in three consecutive generations, and four pedigrees with diabetes in four consecutive generations. Fig. 3 shows the proportion of

Table 4

\begin{tabular}{lrllccccccc}
\hline & Decades I & II & III & IV & V & VI & VII & VIII & IX & Total \\
\hline $\mathrm{n}_{i}$ & 0 & $\mathbf{1 3}$ & 29 & 72 & 112 & 71 & 22 & 7 & 0 & 326 \\
$\mathrm{n}_{j}{ }_{j}$ & 15 & 24 & 85 & 164 & $\mathbf{2 2 3}$ & $\mathbf{2 0 2}$ & $\mathbf{1 0 1}$ & 30 & 3 & 847 \\
$p_{j}$ & 1 & 0.960 & 0.872 & 0.651 & 0.307 & 0.089 & 0.0215 & 0 & 0 & \\
\hline
\end{tabular}

\section{Diabetic couples}

On May 1, 1967, 484 couples, where both partners were diabeties, were on the files of the Antidiabetic Centre of Bucharest; 99 of these couples had no children. The other 385 couples had 1173 descendents, of which 326 developed diabetes $(27.7 \%)$. For interpretation of these figures, the probability of diabetes was calculated - had all the offspring lived and been followed up for 9 decades. The analytical data are given in Table 4 (for symbols see under material and method). the offspring affected and the way in which the cases were selected: diabetes in multiple successive generations but no diabetes in the related families.

The highest density of the cases was:

with 3 generations $=88$ pedigrees of $1079=8.15 \%$ with 4 generations $=3$ pedigrees of $253=1.19 \%$

The presence of these cases and their relatively high frequency in the pedigrees followed up for many years is a further argument in favour of the dominant transmission of diabetes. Indeed, if the appearance of the disease in two consecutive generations may be a casual 
occurrence in recessive diseases too, its consecutive appearance in several generations, apart from consanguine marriages, and provided one of the parents is diabetic, pleads for a dominant transmission.

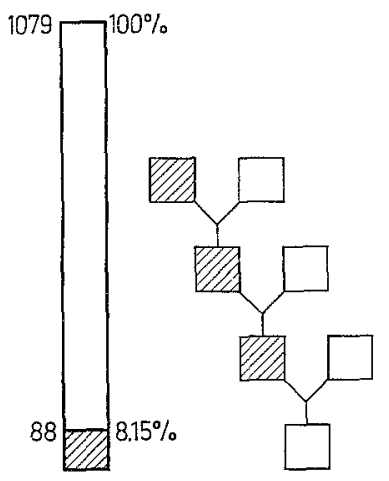

A

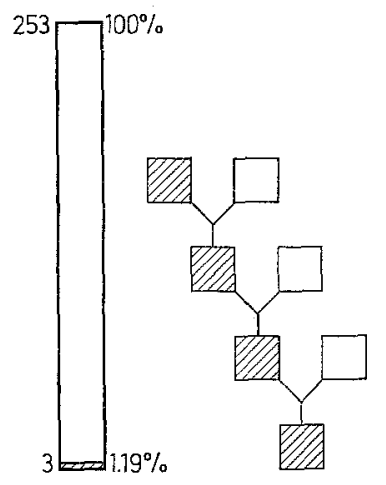

B
Fig. 3. Diabetes mellitus in several successive generations (prevalence and screening of the cases). $a=3$ generations; $\mathrm{b}=4$ generations

\section{Anteposition ${ }^{2}$}

In the forementioned work, [14] we showed that in the course of several generations diabetes has a tendency to appear earlier in the descendants than in the parents. Among the 144 relatives of the 1st degree we found:

- anteposition, i.e. a mean difference of 16.4 years, in 87 cases;

- retroposition, i.e. a mean difference of 10.56 years, in 50 cases and

- isoposition in 7 of the 144 relatives of the first degree investigated. Statistical calculations show the difference to be significant for anteposition. The anteposition phenomenon likewise appears to be an argument in favour of dominant transmission. The genetic equipment degraded under the action of environmental factors can only be heterozygote, and this in turn is compatible with dominant transmission alone.

\section{Comments}

The four categories discussed: the heredity of consanguine couples, the heredity of diabetic couples, diabetes in 3 and 4 successive generations, and anteposition, actually represent the four steps of the research which led us to the conclusion of the dominant transmission of hereditary diabetes.

1. Analysis of consanguine marriages in families with multiple cases of diabetes supplies an argument against the resessive transmission of the disease, in so far as the prevalence of diabetes is not greater in the offspring than in the foci without consanguinity. On the

2 The Editorial Board leaves the authors responsible in regard to the value of the anteposition in inherited diabetes. other hand, there is no massive outbreak of the disease among siblings, neither is the onset earlier than in the case of the current diabetic endemy.

2. Study of the descendants when both parents are diabetics of the hereditary type shows the prevalence of diabetes to be only $27.7 \%$, and the probability of diabetes among these descendants, if they lived to 90 years, rises only to $37.65 \%$. With recessive transmission these diabetic couples, having the hereditary disease, ought to be homozygotes, and the probability of diabetes in the descendants should tend towards $100 \%$. The proportion of over $62 \%$ of the offspring of diabetic couples that would remain healthy even if they were to live 90 years leads to the conclusion that the great majority of the parents are heterozygotes, which is compatible with dominant transmission alone. Similar figures were reported by Cook, FitzGeraId, Macins and Prke [3] who found diabetes in only up to a quarter of the descendants. Although they did not include the probability of diabetes if all the descendants lived up to the age limit, they interpreted their findings in the same sense as we do.

3. The existence of pedigrees in which diabetes appears in multiple successive generations ( 3 and 4 generations), with heredo-collateral antecedents on one side only, and without consanguinity, is a further argument lending support to the dominant transmission of diabetes; i.e. the disease may be transmitted by a single carrier allele. This likewise pleads for the heterozygote structure of diabetics of the hereditary type.

4. Anteposition, signalled by Woonyatr and SPETz [22], presents a net statistical significance as shown in our previous work [14], although authors such as Steinberg consider it biologically meaningless. In our opinion this phenomenon upholds the dominant transmission of diabetes. Indeed, if diabetes develops earlier from one generation to another, and if the gravity of the disease is inversely proportional to the age at which it develops, then the anteposition shows capitalization of the wear and tear from one generation to another; otherwise stated hereditary resistance to environmental factors decreases. This resistance, linked to the genetic structure, is due to the protective role of the non-carrier allele, as we already showed in a previous work [13]. In this connection, CooK et al. [3] observed that diabetes appears more frequently in the children of diabetic parents that developed the disease at an earlier age; and Oкамото [12], who produced alloxan diabetes in successive generations of rats, was able to bring about experimental hereditary diabetes in the course of 5-7 generations. This shows that in most cases diabetics of the hereditary type present a heterozygote structure, which implies the dominant transmission of diabetes.

The irregular penetrance and different expressivity from one case to another, may be accounted for by the protective role of the non-carrier allele that can be influenced by environmental factors to a greater or lesser extent. 


\section{References}

1. Alten, W.: Heredity in diabetes mellitus. Ann. Int. Med. 6, 1272-2274 (1953).

2. Cammoge, P.J.: Diabetes mellitus and heredity. Brit. Med. J. 1928 II, 738-741.

3. Cook, A.M., M.G. Finzgeratd, J.M. Matins, and D.A. PYKE: Diabetes mellitus to progeny from diabetic couples. Brit. med. J. 1966 II, $674-676$.

3a. -, A. Gronberg, T. Larsson, and J. JUNG: Diabetes in Sweden. Acta med. scand. Suppl. 477 (1967).

4. Gronnet, J.: Heredity in diabetes mellitus. Copenhagen: Munksgaard 1953.

5. Gunther, O.: Probleme der Genetik des Diabetes mellitus. Der Internist 4, 374-384 (1963).

6. Harris, H.: The familial distribution of diabetes mellitus. Ann. Eugen. 15, 95-119 (1950).

7. KRIES, I. von: Beitrag zur Genetik des Diabetes mellitus. Z. menschl. Vererb.- u. Konstit.-Lehre 31, $406-430$ (1953).

8. Layry, M., J. Frezal, and J. Rey: Hérédité du diabête sucré. Journées Ann. Diabetolog. Hôtel-Dieu. Paris: Flammarion 1961.

9. LAWRENot, R. D. : The Chances of Morbid Inheritance. London: Blacker 1934.

10. Levit, S.G., and N.L. Perssrkova: The genetics of diabetes mellitus. Proc. M. Gorky Med. Biol. Inst. 3, $132-147$ (1934).

11. Negt, J.V., S.S. Fajans, J.W. Conn, and R.T. DAvIDson: Diabetes mellitus. In Geneties and Epidemiology of Chronic Diseases. U.S. Public Health Serv. Publ. vol. 1163, p. 105, 1965. 11a. NIISSON, S.E.: On the heredity of diabetes mellitus and its interrelationship with some other diseases. Acta Genet. 14, 96-110 (1964).

12. Okamoro, $K .:$ In $O n$ the Nature and Treatment of Diabetes Mellitus, p. 627. Amsterdam: Excerpta med. 1965.

13. Paver, I., and R. Preptea: Problèmes que pose l'hérédité diabétique. Journées Ann. Diabetolog. HôtelDieu. Paris: Flammarion 1965.

14. - - Le diabète héréditaire au cours de 3 et 4 généra. tion successives. Diabetologia 2, 281-285 (1966).

15. - - Hereditatea diabeticá. 1 vol. 148 pag. Ed. Acad. R.S. România Bukarest 1968.

16. Prncus, G., and P. White: On the inheritance of diabetes mellitus. Amer. J. med. Sci. 186, 1-14 (1933).

17. - - On the inheritance of diabetes mellitus III Amer. J. med. Sci. 188, 782-790 (1934).

18. Post, R.H.: Does all diabetes depend upon a single genetic locus ? Amer. J. Human. Genet. 11, 56-65 (1962).

19. Stmpson, N.: The genetics of diabetes. Diabetes 5 , $462-466(1964)$.

20. StennberG, G.A., and R. WIIDER: A study of the genetics of diabetes mellitus. Amer. J. Fluman. Genet. $4,113-135$ (1952).

21. ToMpson, M. W., and E.M. WATson: The inheritance of diabetes mellitus. Diabetes 1, 268-275 (1952).

22. Woonjatr, R.T., and M. Spertz: Anticipation in the inheritance of diabetes. J. amer. med. Ass. 120, $602-$ 605 (1942).

Prof. Dr. I. Pavet Intrarea Caragiale Nr. 6

Bucarest 13

Rumänien

D. R. Preptea

Str. Dragos-Voda 37

Bucarest 9

Rumänien 